\title{
The Effect of Principal Managerial Competence in Developing Cultural Organization and Job Satisfaction MTs Teacher in Jambi
}

\author{
Alius $^{1}$, Hamzah $^{2}$, Kompri $^{3}$, Dr. Maisah, M.Pd.I ${ }^{4}$ \\ ${ }^{1,2,3}$ Doctor Candidate in Institute Agama Islam Negeri Sulthan Thaha Saefuddin (IAIN STS) Jambi \\ ${ }^{4}$ PostgraduateLecture in Institute Agama Islam Negeri Sulthan Thaha Saefuddin (IAIN STS) Jambi
}

\begin{abstract}
The quality and success of teachers in performing their duties very influenced by some key variables, namely: the principal managerial competencies, organizational culture and job satisfaction of teachers. Therefore, these three variables should receive serious attention from various parties to ensure quality education. MTS is one of the organizations at the level of secondary education-based religion (Islam). Thus coaching junior teachers is something that is very important to create high-quality graduates. Research with quantitative approach with a survey method that involves 12 MTs principals and 40 teachers MTs in Jambi found that: (1) there is a direct effect of the positive and significant correlation between managerial competencies principals $(X)$ of organizational culture (Y1) in the environment MTs in the city of Jambi. With $37.578 \mathrm{~F}_{\text {calculate }}$ being $F_{\text {table }} 3.90$ at 0.05 probability. Therefore $\mathrm{HO}$ is rejected and $\mathrm{H1}$ accepted, (2) there is no direct effect positive and significant correlation between managerial competences of principals (X) to job

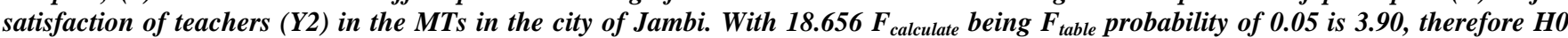
and $\mathrm{H1}$ rejected. With these results it is suggested policy makers in the department of religion of Islam and the stakeholders in the neighborhood MTs in Jambi need to take concrete steps to ensure that their schools have a culture and values that guarantee the existence of MTs in Jambi times next to the level of job satisfaction of a good teacher.
\end{abstract}

Keywords: managerial ability of principals, organizational culture, job satisfaction, MTs.

\section{Introduction}

Education is a long process and very important in improving the quality of human resources. Human resources excellence will support the quality of human life, so that the quality of education should be the concern of many parties. Several factors affect the quality of education, for example: the quality of teachers is the teacher, the students as learners, facilities and infrastructure, the available budget, management systems and so on. These factors, directly or indirectly affect the educational process conducted by an educational institution. Therefore, it takes a leader who is reliable, has a good competence so as to manage the variables that affect the educational process.

An educational institution that has a quality leader, the leader who master a wide range of leadership theory and educational theory as well as be able to apply these theories are correct and accurate, the results of the educational process at the institute will also be qualified. Likewise, institution leaders poor education quality will also be a hedge on the low quality of education from institutions that lead. One of the capabilities or competencies required by the leader of the institution is the managerial competence.

\subsection{Managerial Competence Principal}

In a large dictionary Indonesian competence is the authority or power to determine or decide something. According to Spencer (1993) competence is the basic foundation of his characteristics and indicate how to behave or think, likens the situation and support for a long period of time. Zwell (2000) states that competence is an ability to perform or do a job that is based on skills and knowledge and supported work attitude demanded by the job. As according Wibowo (2009) competencies are individual characteristics that underlie performance or behavior at work.

Referring to the definition above, it can be understood that competence is a rational behavior of a person to achieve the objectives in accordance with the conditions expected. In order to do something at work, people must have the ability in the form of knowledge, attitudes, and skills in accordance with the field work.

Associated with managerial competence Zwell (2000) mentions that managerial competencies are specifically related to the management, supervision and development of others. Managerial competencies include: motivate, empower and develop others. The same thing was also conveyed by Sutopo (1999) that the management function includes the following activities: (a) planning (budgeting, programming, decision making, forecasting), (b) organizing (structuring, assembling resources, staffing), (c) the mobilization (coordinating, directing, commanding, motivating, leading, motivating), and (d) surveillance (monitoring, evaluating, reporting).

At the National Education Minister Regulation No. 13 of 2007 states that a school principal should have five competencies. The fifth of these competencies are: (1) personal competence, (2) social competence, (3) managerial competence, (4) entrepreneurial competence and (5) the competence of supervision. Associated with managerial competence principals, according to Sudrajat (2012) elaborated / developed as follows, namely: (a) competent in planning the school, in this case, the principal needs some skill, among others: (1) is able to master the theories 


\section{International Journal of Science and Research (IJSR) \\ ISSN (Online): 2319-7064}

Index Copernicus Value (2013): 6.14 | Impact Factor (2015): 6.391

associated with the planning, both in the short, medium and long term, (2) is able to plan the development of schools that uphold the principles of the preparation of the strategic plan that is good and true, (3) is able to makes up the development of an operational plan based on the approach and principles good preparation of operational plans, (4) able to suckle school budget plan, and others, (b) competent in mastering the theory and national education policy in the management of school institutions, (c) competent in the lead teachers and all educational staff in order to utilize human resources and accurately.

Related with the principal function as a manager, Stoner (1982) suggested that the presence of the manager in an organization is necessary. According to Stoner last eight functions of a manager is to be implemented in a organizationon namely: (1) work and through others, (2) the time and limited resources to face various problems, (3) responsible, (4) think realistic and conceptual, (5) is the mediator, (6) is a political, (7) is a diplomat, (8) a difficult decision. Therefore, principals should have four main competencies and skills in managerial organization, which makes planning skills, organizational skills resource, conducting skills, and skills to control and evaluation.

Referring to the concept of managerial competencies as mentioned above, there are three important things that need to be considered by the principal as a manager, namely: (1) process, is a way of systemic doing things, (2) resources of schools, including funds, equipment, information, and human resources, each of which serves as thinkers, planners, perpetrators and supporters to achieve the objective (3) achieving organizational goals predetermined.

\subsection{Organizational Culture}

According Sobirin (2007), organizational culture is a construct abstraction of a phenomenon that can be observed from all sides. According to Schein (2004), organizational culture is a pattern of basic assumptions were explored, discovered and developed by a group of people as they learn to cope with the problem of adaptation external and internal integration, which has been shown to function properly and therefore assumed to be true, so that the pattern submitted against individual members of the organization to have a way of looking and thinking patterns is right and proper to be able to act properly in dealing with the problem. Therefore Deal and Kennedy (1982) give a statement "... emphasis the more visible levels of culture (heroes, rites, rituals, legends and ceremonies) Because it is Reviews These attributes they believe shape behavior .." is the level of culture (which in the form of heroic values, rites, rituals, legends and ceremonies) because they believe these attributes shaping behavior.

Organizational culture positive school may also affect the implementation of high quality education and moral formation and a positive attitude for all personnel in educational institutions. This condition is very supportive of high learning achievement. The school principal has the primary responsibility within the framework of the arrangement of the organizational culture of the school. Thus, a conducive organizational culture will positively affect the quality of the learning process in schools and vice versa. In addition, organizational culture conducive will also have an impact on the performance of the employee, in this case there are teachers and education personnel.

The linkage between organizational culture with the performance of employees (teachers and staff) is expressed by Judge (2011) that organizational culture has a positive correlation to the performance of employees at certain levels. The statement is consistent with the results of research Gonza'lez, Garazo, Teresa Garcia (2006), which faund that a strong organizational culture in an institution or organization will be able to create goals, motivation and effective control. This is because the organizational culture involves many parties are bound to each other organization. Additionally, Scein (1994) also stated that a strong organizational culture will have an impact on the strong performance of employees as well as a strong performance to create a strong organizational culture as well.

Based on the study above, it is understood that organizational culture is ideas, ideas, values and norms agreed together that binds every member of the organization. Thus, the organizational culture directs and determines the members to stay on normative values that apply. In addition, organizational culture also determines the forms of organization and supervision menagerial style leader who can be accepted by the members of the organization.

\subsection{Job Satisfaction}

Everyone who works expect derive satisfaction from work. Basically the job satisfaction is an individual thing for each individual will have a level of satisfaction varies in accordance with the values prevailing in every individual. The more aspects of the work in accordance with the wishes of individuals, the higher the perceived level of satisfaction. According Kreitner and Kinicki (2005) job satisfaction is "an effective or emotional response to various aspects of the job". Davis and Newstrom (1984) described "job satisfaction is a set of unpleasant feeling whether or not an employee of their work". According to Robbins (2009) job satisfaction is "the general attitude towards the work of someone who shows the difference between the number of awards received by workers and the amount they believe they should receive".

Job satisfaction is an affective or emotional responses to the various facets or aspects of a person's job so that job satisfaction is not a single concept. A person can be relatively satisfied with one aspect of the job and not be satisfied with one or more other aspects. Job satisfaction is a positive attitude towards his job workers, which comes under the assessment of the employment situation. The assessment can be performed on one work, the assessment is as respect in achieving one of the important values in the work. A disgruntled employee works more like than not like the situation.

Associated with job satisfaction, Kreitner and Kinicki (2005) says there are five factors that influence job satisfaction, namely (1) inadequate requirements, that the work done by an employee is believed to be able to meet their needs, (2) 


\section{International Journal of Science and Research (IJSR) \\ ISSN (Online): 2319-7064}

Index Copernicus Value (2013): 6.14 | Impact Factor (2015): 6.391

the fulfillment of the hope, that in the work is able to meet the expectations of individual workers, (3) the value of that work he did were able to able to provide satisfaction the value of employment, (4) justice, employees will feel satisfied in their work if they are treated fairly in the workplace, and (5) genetic component, that job satisfaction is a function of personal characteristics and genetic factors employees.

Additionally, Kreitner and Kinicki (2005) adds that there are factors that are involved and be decisive employees satisfaction in work. Additional factors are: (1) type of work, if the work in accordance with their interests, skills employees will tend to increase job satisfaction, and vice versa, (2) relations with the leaders (bosses), good relations and harmony will increase the level of satisfaction employment, (3) colleagues (fellow workers), (4) the promotion or sale, (5) the salary or wages received by employees.

Based on the above, it is understood that the satisfaction is something that is very important in an educational institution and can have an impact on the performance of employees in an institution. Therefore, employee satisfaction or employees should be a concern of the leaders in this regard is the principal. The influence of job satisfaction on employee performance is expressed by Arthadi (2015) in a study found that job satisfaction has positive influence on employee performance in PT. Agung Lestari so that the level of job satisfaction can predicting employee performance $12.3 \%$. In addition, the research results Syaiin (2008) also show the same thing, namely job satisfaction has a strong relationship and significant impact on the performance of employees in Medan Bestari Clinic. The study, with similar results, the research Huda (2012) states that there is a positive and significant impact given by job satisfaction on the performance of employees of PT. Joto Bekti Indah Surabaya.

Based on the above research, the employee satisfaction should more serious attention to the opinion of the leaders. According to S. Rahma (2013), employee job satisfaction can be improved by measures appropriate managerial. Such steps are as follows: (1) change the structure of the work, that is by doing job rotation from one form of job to another in accordance with the employee's skills and adapted to her job description, (2) changes salary structure adapted to type of work, volume of work, work productivity and skills of employees, (3) the preparation and the implementation of a flexible work schedule while providing control over the employees to always discipline in work and (4) develop a program to support and improve employee job satisfaction, for example by provides a bonus, vacation, health care and others.

\section{Methods}

The research was conducted in the city of Jambi with the aim to determine the effect of principalscompetence managerial of organizational culture and job satisfaction of teachers MTs in the city of Jambi. Thus the research was conducted on MTs in the city of Jambi. The method used is survey method through a causal relationship. This method was chosen because it allows the holding of a broader study with the causal relationship between the variables studied.

In this study, the population is the principal and teachers of MTs in the city of Jambi. To determine how many samples are taken, the formula used McClave as follows:

Where:

$$
\mathrm{SE}=\frac{\mathrm{Sx}}{1+\mathrm{N}(\mathrm{e})^{2}}
$$

SE: The number of samples taken

Sx: Number of total population

$\mathrm{N}$ : Number

Sampling trials will be conducted by means of random sampling, the entire population is to be noted the name, then put in a container and will be drawn randomly. Once the entire sample is obtained, the sample will be contacted for the survey. Data collection techniques used in this study was a questionnaire instrument. Researchers gave questionnaires to all the selected sample. The questionnaire has been sent filled by the respondent. Respondents' answers to the statements of the four variables, namely the principal managerial competence variable $(\mathrm{X})$, organizational culture (Y1) and job satisfaction (Y2) measured by scoring. Instruments developed based on the indicators to be achieved. Instrument developed is a questionnaire that would be filled by the respondent. Measurements using a five-point scale that starts from (1) strongly agree, (2) agree, (3) undecided, (4) disagree, and (5) strongly disagree.

Data processing was performed by descriptive statistical analysis to present data from each variable. Based on the scores obtained, each of the variables were statistically tested, namely normality test, homogeneity and linearity. After these tests done, the next step is to find the influence of managerial competencies principals of organizational culture teacher job satisfaction. For those reasons, then tested the correlation and $\mathrm{F}$ test (test of significance). All statistical tests are performed using SPSS version 2.0

\section{Data and Discussion}

\subsection{Data}

\subsubsection{Normality Test Data \\ Normality Test Variables Principal Managerial Competence $(\mathrm{X})$ to Cultural Organization (Y1)}

Table 3.1: One-Sample Kolmogorov-Smirnov Test

\begin{tabular}{|c|c|c|c|}
\hline \multicolumn{2}{|c|}{} & $\begin{array}{c}\text { Principal } \\
\text { Managerial } \\
\text { Competence }\end{array}$ & $\begin{array}{c}\text { Cultural } \\
\text { Organization }\end{array}$ \\
\hline \multirow{2}{*}{$\begin{array}{c}\text { Normal } \\
\text { Parameters }\end{array}$} & Mean & 105,8983 & 261,6271 \\
\hline \multirow{2}{*}{$\begin{array}{c}\text { Most Extreme } \\
\text { Differences }\end{array}$} & Std. Deviation & 25,14663 & 27,04619 \\
\cline { 2 - 4 } & Absolute &, 060 &, 085 \\
\cline { 2 - 4 } & Positive &, 060 &, 040 \\
\hline Kolmogorov-Smirnov Z &,- 050 &,- 085 \\
\hline Asymp. Sig. (2-tailed) &, 798 & 1,132 \\
\hline \multicolumn{2}{|l|}{ a. Test distribution is Normal. } &, 547 &, 154 \\
\hline \multicolumn{2}{|l|}{ b. Calculated from data. } \\
\hline
\end{tabular}




\section{International Journal of Science and Research (IJSR) \\ ISSN (Online): 2319-7064 \\ Index Copernicus Value (2013): 6.14 | Impact Factor (2015): 6.391}

Based on Table 3.1 above, it appears that the significance value (Asymp. Sig. (2-tailed) for managerial competence principal is 0.547 while for the culture of the organization amounted to 0,154 . The significance value $>$ than 0.05 . Thus, the data managerial competencies head school and organizational culture are normally distributed, so that it can be done in more statistical tests.

Normality Test Variables Principal Managerial Competence (X) on Job Satisfaction of Teachers (Y2)

Table 3.2: One-Sample Kolmogorov-Smirnov Test

\begin{tabular}{|c|c|c|c|}
\hline & & Principal Managerial Competence & Job Satisfaction of Teachers \\
\hline \multicolumn{2}{|l|}{$\mathrm{N}$} & 54 & 54 \\
\hline \multirow{2}{*}{ Normal Parameters } & Mean & 111,6045 & 261,6271 \\
\hline & Std. Deviation & 15,14256 & 27,04619 \\
\hline \multirow{3}{*}{ Most Extreme Differences } & Absolute & 047 & 085 \\
\hline & Positive & ,047 &, 040 \\
\hline & Negative &,- 046 &,- 085 \\
\hline \multicolumn{2}{|l|}{ Kolmogorov-Smirnov Z } & ,630 & 1,132 \\
\hline \multicolumn{2}{|l|}{ Asymp. Sig. (2-tailed) } & 823 &, 154 \\
\hline \multicolumn{4}{|l|}{ a. Test distribution is Normal. } \\
\hline
\end{tabular}

Based on the table above, it appears that the significance value (Asymp. Sig. (2-tailed) for managerial competence principal is 0.823 while for satisfaction amounted to 0,154 . The significance value $>$ than 0.05 . Thus, the data principalmanagerial competencies and Job satisfaction normally distributed so as to do statistical tests are more.

\subsubsection{Homogeneity test}

Homogeneity Managerial Competence Principal (X) to Cultural Organization (Y1)

Table 3.3: ANOVA Table (X) Vs Y1)

\begin{tabular}{|c|c|c|c|c|c|c|c|}
\hline \multicolumn{2}{|c|}{} & Sum of Squares & df & Mean Square & F & Sig. \\
\hline \multirow{3}{*}{$\begin{array}{c}\text { Principals managerial } \\
\text { competencies * Job } \\
\text { satisfaction }\end{array}$} & \multirow{3}{*}{$\begin{array}{c}\text { Between } \\
\text { Groups }\end{array}$} & (Combined) & 70371,742 & 53 & 1066,239 & 2,009 &, 001 \\
\cline { 2 - 9 } & & Linearity & 22758,371 & 1 & 22758,371 & 42,888 &, 000 \\
\cline { 2 - 9 } & & Deviation from Linearity & 47613,371 & 45 & 732,513 & 1,380 &, 068 \\
\cline { 2 - 9 } & Within Groups & 58371,648 & 110 & 530,651 & & \\
\hline
\end{tabular}

According to Table 3.3. ANOVA tests above, it can be seen that the value sig linearity deviation between the principal managerial competence variable $(\mathrm{X})$ to the culture of the organization is 0.068 . Based provision that if $\operatorname{sig}>0.05$ then the data homogeneous. Therefore, based on the test data on both variables homogeneous

Normality Test Principal managerial competence $(\mathrm{X})$ and Teacher job satisfaction (Y2)

Table 3.4: ANOVA Table (X2 Vs Y)

\begin{tabular}{|c|c|c|c|c|c|c|c|}
\hline & & & Sum of Squares & $\mathrm{df}$ & Mean Square & $\mathrm{F}$ & Sig. \\
\hline \multirow{5}{*}{$\begin{array}{c}\text { Principal managerial } \\
\text { competency* } \\
\text { Teacher job satisfaction }\end{array}$} & \multirow{3}{*}{$\begin{array}{c}\text { Between } \\
\text { Groups }\end{array}$} & (Combined) & 70944,190 & 53 & 945,923 & 1,653 &, 009 \\
\hline & & Linearity & 12402,867 & 1 & 12402,867 & 21,673 &, 000 \\
\hline & & Deviation from Linearity & 58541,322 & 44 & 791,099 & 1,382 &, 065 \\
\hline & \multicolumn{2}{|r|}{ Within Groups } & 57799,200 & 101 & 572,269 & & \\
\hline & \multicolumn{2}{|r|}{ Total } & 128743,390 & 54 & & & \\
\hline
\end{tabular}

Based on Table 3. 4. ANOVA tests above, it can be seen that the value sig linearity deviation between the principal variables managerial competencies and job satisfaction is 0.065 . Based provision that if $\mathrm{sig}>0.05$ then the data homogeneous. Therefore, based on the test data on both variables are homogeneous.

\subsubsection{Correlation}

Principal Managerial Competence (X) to Cultural Organization (Y1)
Table 3.5: Correlations Tes (X Vs Y1)

\begin{tabular}{|c|c|c|c|}
\hline \multicolumn{2}{|c|}{} & $\begin{array}{c}\text { Principal } \\
\text { Managerial } \\
\text { Competence }\end{array}$ & $\begin{array}{c}\text { Cultural } \\
\text { Organization }\end{array}$ \\
\hline $\begin{array}{c}\text { Principal } \\
\text { Managerial } \\
\text { Competence }\end{array}$ & Pearson Correlation & 1 &, $478^{* *}$ \\
\cline { 2 - 4 } & Sig. (2-tailed) & &, 000 \\
\hline \multirow{2}{*}{$\begin{array}{c}\text { Cultural } \\
\text { Organization }\end{array}$} & Pearson Correlation &, $478^{* *}$ & 54 \\
\cline { 2 - 4 } & Sig. (2-tailed) &, 000 & 1 \\
\cline { 2 - 4 } & $\mathrm{N}$ & 54 & 54 \\
\hline
\end{tabular}

**. Correlation is significant at the 0.01 level (2-tailed).

Based on the significant value with the value obtained for 0,478 probability Sig. (2-tailed) her 0,000 . The probability the value $<0.05$. Thus, there is a significant correlation between the dependent variable (the managerial capacity of 


\section{International Journal of Science and Research (IJSR) \\ ISSN (Online): 2319-7064}

Index Copernicus Value (2013): 6.14 | Impact Factor (2015): 6.391

principal) with free variables Organizational Culture. In addition, under an asterisk (SPSS output) is seen between the two variables have two stars, it shows that both variables have a significant correlation.

\section{Principal Managerial Competence $(X)$ on Job Satisfaction (Y2)}

Table 3.6: Correlations Tes (X Vs Y2)

\begin{tabular}{|c|c|c|c|}
\hline \multicolumn{2}{|c|}{} & $\begin{array}{c}\text { Principal } \\
\text { Managerial } \\
\text { Competence }\end{array}$ & $\begin{array}{c}\text { Job } \\
\text { Satisfaction }\end{array}$ \\
\hline $\begin{array}{c}\text { Principal } \\
\text { Managerial } \\
\text { Competence }\end{array}$ & Pearson Correlation & 1 &, $333^{* *}$ \\
\cline { 2 - 4 } & Sig. (2-tailed) & &, 000 \\
\hline \multirow{2}{*}{$\begin{array}{c}\text { Job } \\
\text { Satisfaction }\end{array}$} & 54 & 54 \\
\cline { 2 - 4 } & Pearson Correlation &, $333^{* *}$ & 1 \\
\cline { 2 - 4 } & Sig. (2-tailed) &, 000 & 54 \\
\hline \multirow{2}{*}{ N } & 54 & . Correlation is significant at the 0.01 level (2-tailed). \\
\hline
\end{tabular}

According to Table 3.6. Correlations Test (X Vs Y2) note the significant value of 0.333 with values obtained probability Sig. (2-tailed) her 0,000 . The probability the value $<0.05$. Thus, there is a significant correlation between the dependent variable (the managerial competence principal) with the independent variable is job satisfaction. In addition, under an asterisk (SPSS output) is seen between the two variables have two stars, it shows that both variables have a significant correlation.

\subsubsection{Regression Test (Effect) and Significance Principals Managerial Competence (X) to Cultural Organization (Y1)}

Table 3.7: Model Summary (X Vs Y1)

\begin{tabular}{|l|l|l|l|l|}
\hline Model & R & R Square & $\begin{array}{l}\text { Adjusted R } \\
\text { Square }\end{array}$ & $\begin{array}{c}\text { Std. Error of } \\
\text { the Estimate }\end{array}$ \\
\hline 1 &, $420^{\mathrm{a}}$ &, 177 &, 172 & 24,610 \\
\hline \multicolumn{4}{|c|}{ a. Predictors: (Constant), Managerial Competence } \\
\hline
\end{tabular}

Table 3.7. Model Summary (X Vs Y1) above show that the price of $\mathrm{R}$ is 0.420 with the percentage of independent variables on the dependent variable is called coefficient of determination which is the result of squaring the value $R$. Thus, the influence of Managerial Competencies to Organizational Culture 17.7 while the remaining $82.3 \%$ is affected though other factors.

Table 3.8: ANOVA $^{\mathrm{a}}$

\begin{tabular}{|c|c|c|c|c|c|c|}
\hline \multicolumn{2}{|c|}{ Model } & Sum of Squares & df & Mean Square & F & Sig. \\
\hline \multirow{2}{*}{1} & Regression & 22758,371 & 1 & 22758,371 & 37,578 &, $000^{\mathrm{b}}$ \\
\cline { 2 - 7 } & Residual & 105985,019 & 53 & 605,629 & & \\
\cline { 2 - 7 } & Total & 128743,390 & 54 & & & \\
\hline \multicolumn{6}{|c|}{ a. Dependent Variable: cultural organization } \\
\hline \multicolumn{6}{|c|}{ b. Predictors: (Constant), Managerial Competence } \\
\hline
\end{tabular}

Based on Table 3.8 above obtained value $F_{\text {calculate }} 37.578$ with significance level (probabilityy) 0,000. The probability of $<0.05$, the regression model can be used to predict the participation variable. In other words, a significant regression.
Table 3.9: Coefficients

\begin{tabular}{|c|c|c|c|c|c|c|}
\hline \multirow{2}{*}{ Model } & \multicolumn{2}{|c|}{$\begin{array}{c}\text { Unstandardized } \\
\text { Coefficients }\end{array}$} & $\begin{array}{c}\text { Standardized } \\
\text { Coefficients }\end{array}$ & \multirow{2}{*}{ Sig. } & \\
\cline { 2 - 7 } & B & Std. Error & Beta & & \\
\hline \multirow{2}{*}{1} & (Constant) & 198,281 & 10,498 & & 18,888 &, 000 \\
\cline { 2 - 7 } & $\begin{array}{l}\text { Managerial } \\
\text { competence }\end{array}$ &, 562 &, 092 &, 420 & 6,130 &, 000 \\
\hline \multicolumn{6}{|c|}{ a. Dependent Variable: Cultural organizationn } \\
\hline
\end{tabular}

According to Table 3.9, the regression equation can be written as:

$\mathrm{Y}=198,291+0,562 \mathrm{X}$.

Column B is called coefficient regression direction and declared change in average variable $\mathrm{Y}$ for any change in the variable $\mathrm{X}$ by one unit. This change represents an if $\mathrm{B}$ is positive and decrease if negative sign. So, from these equations can explain that:

a) Constants of 198.281 states that if there is no value then the value of the Trust's participation amounted to 198.281.

b) $\mathrm{X}$ regression coefficient of 0.562 states that each additional 1, then the value of increasing the participation of 0.562 .

\section{Managerial Competence (X) on Job Satisfaction of Teachers (Y2)}

Table 3.10: Model Summary

\begin{tabular}{|c|c|c|c|c|}
\hline Model & $\mathrm{R}$ & R Square & $\begin{array}{c}\text { Adjusted } \\
\text { R Square }\end{array}$ & $\begin{array}{c}\text { Std. Error of the } \\
\text { Estimate }\end{array}$ \\
\hline 1 &, $310^{\mathrm{a}}$ &, 096 &, 091 & 25,784 \\
\hline \multicolumn{4}{|c|}{ a. Predictors: (Constant), managerial competence } \\
\hline
\end{tabular}

Table 3.10 above shows that the price of $\mathrm{R}$ is 0.310 with the large percentage of independent variables on the dependent variable is called coefficient of determination which is the result of squaring the value $R$. Thus, the influence of independent variables on the dependent variable $9.6 \%$ while the remaining $90,4 \%$ is affected though other factors.

Table 3.11: ANOVA $^{\mathrm{a}}$

\begin{tabular}{|c|c|c|c|c|c|c|}
\hline \multicolumn{2}{|c|}{ Model } & Sum of Squares & df & $\begin{array}{c}\text { Mean } \\
\text { Square }\end{array}$ & F & Sig. \\
\hline \multirow{2}{*}{1} & Regression & 12402,867 & 1 & 12402,867 & 18,656 &, $000^{\mathrm{b}}$ \\
\cline { 2 - 7 } & Residual & 116340,522 & 53 & 664,803 & & \\
\cline { 2 - 6 } & Total & 128743,390 & 54 & & & \\
\hline \multicolumn{6}{|c|}{ a. Dependent Variable: Job satisfuction } \\
\hline \multicolumn{6}{|c|}{ b. Predictors: (Constant), managerial competence } \\
\hline
\end{tabular}

Based on the above Table $3.11 \mathrm{~F}$ calculate 18.656 values obtained with a significance level (probability) of 0.000 . The probability is $<0.05$, then the regression model can be used to predict the participation variable. In other words, a significant regression.

Table 3.12: Coefficients ${ }^{\mathrm{a}}$

\begin{tabular}{|c|c|c|c|c|c|c|}
\hline \multirow{2}{*}{\multicolumn{2}{|c|}{ Model }} & \multicolumn{2}{|c|}{$\begin{array}{l}\text { Unstandardized } \\
\text { Coefficients }\end{array}$} & \multirow{2}{*}{\begin{tabular}{|c|}
$\begin{array}{c}\text { Standardized } \\
\text { Coefficients }\end{array}$ \\
Beta \\
\end{tabular}} & \multirow[t]{2}{*}{$\mathrm{t}$} & \multirow[t]{2}{*}{ Sig. } \\
\hline & & $\mathrm{B}$ & Std. Error & & & \\
\hline & (Constant) & 226,275 & 8,411 & & 26,902 &, 000 \\
\hline 1 & $\begin{array}{l}\text { Managerial } \\
\text { competence }\end{array}$ & 334, & ,077 & ,310 & 4,319 &, 000 \\
\hline
\end{tabular}

\section{Volume 5 Issue 8, August 2016}




\section{International Journal of Science and Research (IJSR) \\ ISSN (Online): 2319-7064}

Index Copernicus Value (2013): 6.14 | Impact Factor (2015): 6.391

Table 3.12 Based on the above, the regression equation $\mathrm{Y}=$ $226,275+0,334 X$. Thus, the constants of 226.275 states that if there is no value then the value of the Trust's participation amounted to 198.281, while the regression coefficient of $\mathrm{X}$ by 0.334 states that each additional 1 trust, then the value of increasing the participation of 0.334 .

\subsection{Discussion}

\section{Effect of Principal Managerial Competence AgainstCultural Organization}

In a literature review noted that organizational culture is ideas, ideas, values and norms agreed together that binds every member of the organization, so that the culture of the organization will drive and determine the members to stay on normative values applicable, specify forms of organization and supervision managerial style leader who can be accepted by the members of the organization. Moreover, it also has been described by Hofstede (1994) that the elements of the organization are: consists of a group of individuals, have a common goal, which is controlled coordination system, the division of tasks and responsibilities, and have the resources. Thus in brief it can be said that the organizational culture is an effort to implement, ideas, ideas, values, norms and rules in a society involved and work in an organized manner to achieve common goals.

Referring to the above notions, it is understood that there is a clear relationship between the principal managerial competencies with the organization's culture. The existence of a relationship or correlation between the two variables can be seen in Table 3.7. According to Table 3.7 correlation values between the principal managerial competence of the Cultural Organization of 0.420 to $37.578 \mathrm{~F}_{\text {calculate }}$ being $\mathrm{F}_{\text {table }}$ probability of 0.05 is 3.90 . The data shows that the correlation between these two variables is weak. Thus it can be said that the managerial competence of the principal less influence on the culture of the organization. Thus, Ha Ho is rejected and accepted.

Based on the above findings that the managerial competence of the principal impact of organizational culture. Therefore, the school management needs to pay attention to these two variables is more serious. The atmosphere is a positive organizational culture needs to be developed, so as to foster the performance of teachers in the environment MTs in the city of Jambi. This is in line with the suggestions Pattipawae that the organization should be seen as a factor that can influence the emergence of social behavior of an employee organization. Employees with higher affective commitment has a strong emotional attachment to the organization.

With the atmosphere conducive Cultural Organization, will trigger the growth of self-motivation on every teacher to contribute positively to the school organization. Therefore the purpose of organizational culture to change attitudes and behavior of human resources in order to increase labor productivity can be achieved. Due to organizational culture can be formed by those involved with the organization by referring to organizational ethics, work rules, and organizational structures, the involvement of the entire components together in an Organization is a necessity. Kotter and Heskett (1992) states that organizational culture has four important functions, four functions are: (1) provide an organizational identity to the members, (2) to facilitate and facilitate mutual commitment, (3) increase the robustness or stability systemsocial which has been established and (4) forming behavior by helping members choose their work environment. Therefore, together with the organizational structure, organizational culture shaping and control of organizational behavior and the behavior of its employees.

In addition, the development of organizational culture conducive becomes very important considering the variables were highly correlated with the achievement of organizational goals. This is as it has been submitted by O'Riordan (2004) which says that the organization's culture to support career advancement and development and is a strong motivational tool. Construction and development of organizational culture conducive school environment needs to be done by considering the properties Cultural Organization itself. According to Hofstede (1994) the properties of an organizational culture that need to be considered in developing the culture of the organization are as follows: (1) the totality, thorough and touches the dimension of time, (2) reflect the historical accounts of the institution or organization, (3) relate to the situation which are symbolic and ritual, (4) is produced and maintained by individuals together to form a group of organizations, (6) smooth, (6) difficult to change.

With the creation of a conducive atmosphere Cultural Organization, it is expected that the environmental performance of MTs in Jambi increases. Improved performance in each and every individual who is in MTs in Jambi will certainly have a positive impact on the development of the school organization in the future.

\section{Effect of Managerial Competence Principal (X) on Job Satisfaction of Teachers (Y3).}

The quality of leadership will encourage the birth of significantly better quality of education that the school and the students. The statement was in line with the opinion of the Bush (2008) that the quality of leadership makes a significant difference to school and student outcomes. Therefore, leadership is a very important factor in education.

Job satisfaction is an essential requirement for individuals to work. Because people feel positively or negatively influence their work will influence the success or failure of each individual. This is as it has been presented by Colquitt, Lepine, and Wesson (2009) that affect the performance of job satisfaction. Therefore, job satisfaction is an important part in achieving the objectives of the organization, so the existence of job satisfaction should be given serious attention by the campus management.

Related to the relationship between the leadership in this regard is the managerial competence principals on job satisfaction of teachers, the results of data analysis as shown in the results of hypothesis testing shows there is no direct effect positive and significant correlation between managerial competencies principals $(\mathrm{X})$ to job satisfaction 


\section{International Journal of Science and Research (IJSR) \\ ISSN (Online): 2319-7064}

Index Copernicus Value (2013): 6.14 | Impact Factor (2015): 6.391

(Y2) teacher MTs in the neighborhood in the city of Jambi. With $18.656 \mathrm{~F}_{\text {calculate }}$ being $\mathrm{F}_{\text {table }}$ probability of 0.05 is 3.90 , therefore $\mathrm{H} 0$ and $\mathrm{H} 1$ rejected. However, the correlation between the two variables is 0.310 (significant). This means shows that the correlation between managerial competencies principals with MTs teacher job satisfaction has a strong relationship but occur indirectly. Thus it can be said that the principal managerial competence correlated to job satisfaction of teachers MTs but the effect is not direct.

With the already known correlation between managerial competencies Job Satisfaction principals with teachers, the leaders in the MTs in Jambi need to pay attention to the level of job satisfaction of teachers. By increasing the level of job satisfaction of teachers automatically the quality of their work and productivity in the work environment in the city of Jambi MTs will be developed well.

To ensure that employees and lecturers obtain satisfaction in the workplace, then the leaders, especially in the MTs in Jambi need to pay attention to the factors that influence job satisfaction. Associated withMoch. As'ad (2004) stated factors - factors that can lead to job satisfaction as follows: (1) factors among employees, among others, the relationship between managers and staff, physical conditions and the employment situation, the suggestion of a colleague, (2) the individual factors, which is associated with people's attitude to work, the age of people at work, gender, (3) factors external factors include family circumstances employer / employee, recreation, education.

Referring to the suggestions of experts in top leaders in the MTs in Jambi should be able to act and behave professional that job satisfaction of teachers can be assured. Therefore, various factors associated with job satisfaction should be a serious concern in making policies and other programs.

\section{Conclusions and Recommendations}

\subsection{Conclusion}

Based on the description and discussion of the data analysis a number of conclusions. These conclusions are as follows:

1)There is a direct effect of the positive and significant correlation between managerial competencies principals (X) of organizational culture (Y1) in the MTs in the city of Jambi. With $37.578 \mathrm{~F}_{\text {calculate }}$ being $\mathrm{F}_{\text {tabel }} 3.90$ at 0.05 probability. Therefore $\mathrm{H} 0$ is rejected and $\mathrm{H} 1$ accepted

2)There is no direct effect positive and significant correlation between managerial competences of principals (X) to job satisfaction of teachers (Y2) in the MTs in the city of Jambi. With $18.656 \mathrm{~F}_{\text {calculate }}$ being $\mathrm{F}_{\text {table }}$ probability of 0.05 is 3.90 , therefore $\mathrm{H} 0$ and $\mathrm{H} 1$ rejected.

\subsection{Suggestion}

Referring to the discussion that has been described above, there are some suggestions that need attention, both by partners interested in the environment that is stakeholders MTs in Jambi and readers in general. Some ways include:

1) Given the slight positive effect of several variables directly in the environment then the stakeholders MTs in Jambi need to take concrete steps to ensure that the school environment with a culture and values that ensure the existence of MTs in Jambi future.
2) The environmental policy taker MTs in Jambi need work in team with other parties that the experts in order to prepare various programs or policies that enable the creation of organizational culture and job satisfaction. This is because both of these variables will ensure the creation of a good working productivity.

\section{References}

[1] AkmadSudrajat,

KemampuanManajerialKepalaSekolah, www. Andalascommunity. Di aksespadaTanggal 15 Agustus 2012.

[2] Ali ÇağatayKılınç. A Quantitative Study of the Relationship between Distributed Leadership and Organizational Citizenship Behavior: Perceptions of Turkish Primary School Teachers. Journal of Curriculum and Teaching Vol. 3, No. 2; 2014, www.sciedu.ca/jct

[3] Artadi (2015) PengaruhKepuasanKerja Dan BebanKerjaTerhadapKinerjaKaryawanPada Pt. MerapiAgung Lestari. Program StudiManajemen JurusanManajemenFakultasEkonomiUniversitasNegeri Yogyakarta

[4] Bush, Tony. Leadership and Management Development in Education. SAGE Publications Ltd. London EC1Y 1SP, 2008.

[5] Colquitt, Jasson A., Jeffery A. Lepine, dan Michael J. Wesson. Organizational Behavior: Improving Performance and Commitment in the Workplace, Boston: McGraw Hill, 2009.

[6] Daulay, Sere Saghranie. KepemimpinanDalamManajemenPendidikan.

PusdiklatIndustri. 2008.

[7] Davis. Managing Corporate Culture, Cambridge, Belinger, 1984

[8] Deal, T.E. and A.A. Kennedy. Corporate Cultures. Reading, MA: Addison-Wesley. 1982

[9] EbruOguz. The Relationship Between The Leadership Styles of The School Administrators and The Organizational Citizenship Behaviours of Teachers. Procedia Social and Behavioral Sciences 9 (2010) 1188-1193.

[10] Gonza'lez, Jose' Varela \&Garazo, Teresa Garcı'a. (2006). Structural Relationships Between Organizational Service Orientation, Contact Employee Job Satisfaction and Citizenship Behavior. International Journal of Service Industry Management Vol. 17 No. 1, 2006 pp. 23-50.

[11] Hasibuan. Malayu SP., Manajemen: Dasar, PengertiandanMasalah. Jakarta, PenerbitBumiAksara, 2001.

[12] Hakim, Lukman. MembangunBudayaOrganisasiUnggulSebagaiUpaya MeningkatkanKinerjaKaryawan Di Era Kompetitif. (BENEFIT JurnalManajemendanBisnis Volume 15, Nomor 2, Desember 2011).

[13] Hofstede, Geerts. Cultures and Organizations: Software of The Mind.( London: Harper Collins Publishers, 1994), h.96.

[14] Huda, Roisul, PengaruhKepuasanKerjaTerhadapKinerjaKaryawan 


\section{International Journal of Science and Research (IJSR) \\ ISSN (Online): 2319-7064}

Index Copernicus Value (2013): 6.14 | Impact Factor (2015): 6.391

PT. Joyo Bekti Indah Surabaya. FakultasEkonomi, UniversitasWijayaPutera, Surabaya.

[15] Kartono, Kartini, PemimpinandanKepemimpinan. Jakarta: Rajawali Press, 2001.

[16] Kinicki, Angelo and R. Kreitner. Organizational Behavior Key concepts skills and best Practice, McGraw-Hill, New York, 2005.

[17] Kotter, Jhon P. andHeskett, James L. Corporate Culture and Performance, (New York: The Free Press, A Division of Mac Millan, Inc., 1992)

[18] Hanif Al RizaL. Pengaruh Budaya Organisasidan Kepuasan Kerja Terhadap KinerjaKaryawan (Studipada RumahSakit PantiWilasa "Citarum" Kota Semarang). Skripsi. FakultasEkonomika Dan BisnisUniversitasDiponegoro Semarang. 2012.

[19] Manik, EsalonaAnilena. PengaruhBudayaOrganisasiTerhadapKepuasanKerja KaryawanPada PT. TrakindoUtama Medan. 2009.

[20] Mastuti, Fauziyah, PolaKepemimpinanOrganisasiPendidikan Di Jawa Tengah Ditinjau Dari Filsafat PendidikanMenurut Kaplan. (Program Studi Magister AdministrasiPublik, KonsentrasiPelayananPendidikan, Angkatan Xxvi. UniversitasDiponegoro, 2009.), h.2

[21] Mulyasa, E. MenjadiKepalaSekolahProfesional, Bandung: RemajaRosdakarya, cetke-VII, 2007.

[22] O'Riordan, J. Developing a Strategic Approach to HR in the Irish Civil Service, CPMR Discussion Paper 26, Dublin: IPA.2006. h.77.

[23] PeraturanMenteriPendidikanNasionalTentangStandarK epalaSekolah/madrasah Nomor 13 TanggalTahun 2007.

[24] Raihani, KepemimpinanKepalaSekolahTransformatif, Yogyakarta: LkiS Printing Cemerlang, 2010

[25] Robbins, S.P., and T.A., Judge, Organizational Behavior, Pearson Prentice Hall, United State of America, New York, 2009.

[26] Rahma., G. A. Suhandana, Ni Kt. Suarni., KontribusiEfektivitasKepemimpinan, Budaya Oranisasidan EtosKerja Terhadap Kepuasan KerjaPegawaiBalaiDiklatKeagamaan Denpasar.eJournal Program Pascasarjana UniversitasPendidikanGanesha Program StudiAdministrasiPendidikan (Volume 4 Tahun 2013)

[27] Schein, Edgar H. Organizational Culture and Leadership. 3rd ed. The Jossey-Bass business \& management series. 2004

[28] Stoner, James A.F., Management, Secont Edition. Englewood Cliffs: Prentice Hal Inc, 1982.

[29] Sutopo, AdministrasimanajemendanOrganisasi. Jakarta: LembagaAdministrasi Negara, 1999.

[30] Spencer, Lyle, M.Jr. dan Signe M.Spencer. 1993. Competence at Work. New York: John Wiley\&Sons, Inc

[31] Syafaruddin, ManajemenMutuTerpadudalamPendidikan. Jakarta, Grasindo, 2002.

[32] Syaiin, Subakti PengaruhKepuasanKerjaterhadapKinerjaPegawai di KlinikSpesialisBestari Medan Tahun 2007. Tesis. Pascasarjana, Universitas Sumatera Utara, Medan.

[33] Ung Hee Lee, HyeKyoung Kim and Young Hyung Kim. Determinants of Organizational Citizenship
Behavior and Its Outcomes. Global Business \& Management Research: An International Journal Vol. 5, No. 1, 2013.

[34] Wibowo.2009. ManajemenKinerja. Jakarta:RajawaliPers

[35] ZirghamullahBukharidan Umar Ali. Relationship between Organizational Citizenship Behavior \& Counterproductive Work Behavior in the Geographical Context of Pakistan. International Journal of Business and Management 2009, Vol. 4, No. 1, p. 85-92.

[36] Zwell, Michael. 2000. Creating a Culture of Competence. New York: John Wiley \& Sons, Inc. 